\title{
KAJIAN TEORITIS MENGENAI INCREMENTAL VALUE - RELEVANCE INFORMASI LABA DAN ARUS KAS DENGAN MEMPERTIMBANGKAN SIKLUS HIDUP PERUSAHAAN
}

\author{
Siti Nur Hidayati
}

ABSTRAKSI

\begin{abstract}
Kajian teoritis ini bertujuan untuk mengetahui incremental value - relevance informasi laba dan arus kas. Hal ini berkaitan dengan para investor dan kreditur sebagai pemakai informasi akuntansi yang mengandalkan informasi laba dalam menilai kinerja perusahaan. Sedangkan, arus kas menyajikan informasi tambahan dalam penilaian tersebut. Selain dua ukuran kinerja tersebut, siklus hidup perusahaan juga dapat memberikan gambaran yang lebih baik.

Metode yang digunakan dalam kajian teoritis ini adalah studi pustaka. Data yang dikumpulkan merupakan hasil penelitian di luar negeri dan di Indonesia. Penelitian yang dimaksud meneliti tentang informasi laba dan arus kas serta hubungan siklus hidup perusahaan dengan informasi laba dan arus kas.

Berdasarkan kajian teoritis yang dilakukan menunjukkan bahwa dengan mempertimbangkan faktor siklus hidup perusahaan, informasi laba dan arus kas memiliki incremental value - relevance yang sangat berguna bagi para investor dan kreditor untuk menilai kinerja akuntansi perusahaan ketika mereka menggunakan keduanya secara bersama - sama.
\end{abstract}

Kata kunci: incremental value - relevance, informasi laba, informasi arus kas, siklus hidup perusahaan.

\section{PENDAHULUAN}

Perusahaan (corporate) secara umum didefinisikan sebagai organisasi dimana sumber daya (input) seperti bahan baku dan tenaga kerja diproses untuk menghasilkan barang dan jasa (output) bagi pelanggan. Pada umumnya tujuan dari perusahaan adalah untuk memaksimumkan laba (profit oriented). Laba diartikan sebagai selisish antara jumlah yang diterima pelanggan atas barang atau jasa yang dihasilkan dengan jumlah yang dikeluarkan perusahaan untuk membeli sumber daya untuk menghasilkan barang atau jasa tersebut.

Jika dilihat dari kegiatan utama yang dijalankan, secara garis besar terdapat tiga jenis perusahaan yaitu pabrikan (manufacturing), perusahaan dagang, dan perusahaan jasa. Perusahaan manufaktur adalah jenis perusahaan yaung kegiatan utamanya mengubah input menjadi produk (output). Perusahaan dagang kegiatan utamanya adalah membeli barang jadi dan menjualnya kembali tanpa melakukan 
pengolahan sebelumnya. Sedangkan menghasilkan jasa bagi pelanggan merupakan kegiatan utama dari perusahaan jasa.

Fokus utama pelaporan keuangan adalah informasi mengenai laba dan komponennya. Menurut John R. Dorfman (1987) yang dikutip dari Warren et.al (1999), di masa lalu investor dan kreditur sebagai pemakai informasi akuntansi mengandalkan sepenuhnya pada informasi laba perusahaan dalam menilai kinerja perusahaan. Guna menyediakan informasi tambahan, sekarang semakin banyak investor dan kreditor yang juga berfokus pada arus kas.

Laporan arus kas (statement of cash flows) menyajikan informasi yang berguna mengenai kemampuan perusahaan dalam meningkatkan kas dari aktivitas operasi, mempertahankan dan memperluas kapasitas operasi, memenuhi kewajiban keuangannya dan membayar dividen (Warren et. al, 1999: 44). Informasi ini membantu investor, kreditur, dan pihak lain dalam menilai kemampuan perusahaan dalam memperoleh laba dan kemampuannnya untuk membayar utang yang jatuh tempo. Laporan arus kas juga berguna bagi manajer untuk menilai aktivitas operasi di masa lalu dan merencanakan aktivitas operasi, investasi, dan pembelanjaan di masa depan.

Laba dan arus kas merupakan dua ukuran kinerja akuntansi perusahaan. Dengan melihat keduanya diharapkan investor dan kreditur dapat mengevaluasi kinerja perusahaan pada suatu saat tertentu. Namun pada kenyataanya, hanya sedikit perusahaan yang menggunakan baik laba dan arus kas untuk menilai kinerja manajemen (Dechow dalam Black, 1998). Agar dapat menggambarkan secara baik kondisi ekonomi serta prospek perusahaan di masa depan, maka yang harus dipertimbangkan selanjutnya adalah faktor siklus hidup perusahaan (Atmini, 2002).

Black (1998) menyatakan bahwa perusahaan yang berada pada tahap siklus hidup yang berbeda memiliki karakteristik yang berbeda, seperti laba dan arus kas. Perbedaan tahap siklus hidup perusahaan juga dipertimbangkan pada saat menghitung nilai perusahaan. Value-relevance didefinisikan sebagai kemampuan untuk menjelaskan variasi cross-sectional dalam nilai pasar ekuitas.

Berdasarkan uraian di atas, maka dipandang perlu untuk melakukan kajian teoritis mengenai incremental value - relevance informasi laba dan arus kas dengan mempertimbangkan siklus hidup perusahaan. Sehingga dengan memasukkan faktor ini diharapkan dapat memberikan gambaran bahwa informasi laba dan arus kas memiliki value - relevance. 


\section{PERUMUSAN MASALAH}

Adapun kajian teoritis yang akan dibahas meliputi:

a. Informasi laba dan arus kas,

b. Konsep siklus hidup perusahaan, dan

c. Hubungan siklus hidup perusahaan dengan informasi laba dan arus kas.

\section{PEMBAHASAN}

\section{A. Informasi Laba dan Arus Kas}

Laba, secara umum didefinisikan sebagai selisih pendapatan dan biaya. Sedangkan menurut Beaver (1970) laba didefinisikan dalam istilah sesuatu yang mampu memberikan fungsi kegunaan. Laba memiliki potensi informasi yang sangat penting bagi pihak intern maupun ekstern perusahaan. Informasi laba merupakan komponen dari laporan keuangan perusahaan, menurut statement of financial accounting concept no. 1 tahun (1992), laba memiliki manfaat untuk menilai kinerja manajemen, mengestimasi kemampuan laba yang representatif dalam jangka panjang, memprediksi laba dan menaksir risiko dalam investasi atau kredit.

Watts dan Zimmerman (1986) menyatakan bahwa proses menghasilkan laba akuntansi menunjukkan proses menghasilkan arus kas, hal ini memiliki implikasi terhadap besarnya perubahan harga saham dihubungkan dengan laba yang diharapkan. Menurut Niswonger, Warren, Reeve, dan Fees (1999):

"laporan arus kas melaporkan jumlah kas yang diterima dan dikeluarkan oleh tiga jenis aktivitas yaitu aktivitas oeprasi, investasi, dan pembiayaan. Arus kas dari aktivitas operasi adalah arus kas dari transaksi yang mempengaruhi laba bersih. Arus kas dari aktivitas investasi adalah arus kas dari penjualan investasi, aktiva tetap, dan aktiva tidak berwujud. Arus kas keluar umumnya termasuk pembayaran untuk memperoleh investasi, aktiva tetap, dan aktiva tidak berwujud. Arus kas masuk dari aktivitas pembiayaan termasuk hasil dari penerbitan sekuritas modal seperti saham preferen dan saham biasa. Arus kas masuk juga dapat meningkat dari penerbitan obligasi, utang hipotek, dan utang jangka panjang lainnya. Arus kas keluar aktivitas pembiayaan meningkat dari pembayaran dividen tunai, pembelian kembali saham yang beredar, dan membayar kembali jumlah pinjaman."

Laporan arus kas menyajikan arus kas dari tiga jenis aktivias, yaitu Arus Kas dari aktifitas Operasi (AKO), Arus Kas dari aktifitas Investasi (AKI), dan Arus Kas dari aktifitas Pendanaan (AKP). AKO adalah arus kas dari transaksi yang mempengaruhi laba bersih. AKI adalah arus kas dari transaksi yang mempengaruhi 
investasi dalam aset non lancar. Sedangkan AKP adalah transaksi yang mempengaruhi kewajiban dan ekuitas perusahaan.

Penelitian-penelitian mengenai informasi laba dan arus kas telah banyak dilakukan terutama penelitian yang memfokuskan pada kandungan informasinya. Berikut beberapa ringkasan hasil penelitian - penelitian tersebut.

a. Penelitian di Luar Negeri

1. Bernard dan Strober dalam Atmini (2002)

Tidak mampu mengidentifikasi logika ekonomis yang mendasari cara pasar memahami informasi arus kas dan akrual serta tidak menemukan perbedaan sisitematis antara implikasi arus kas dan akrual, seperti tercermin dalam perilaku harga saham di sekitar penerbitan laporan keuangan terinci.

2. Bowen et. al dalam Atmini (2002)

Menemukan bukti bahwa informasi arus kas konsisten dengan informasi yang terkandung dalam harga sekuritas serta memiliki kekuatan penjelas inkremental melebihi kekuatan penjelas yang terkandung dalam arus akrual itu sendiri.

3. Livnat dan Zarowin dalam Black (1998)

Menemukan bahwa disagregasi laba bersih ke dalam kas dari operasi dan akrual tidak memberikan sumbangan yang signifikan terhadap asosiasi dengan return sekuritas melebihi kontribusi laba itu sendiri. Disagregasi arus kas pendanaan dan operasi ke dalam komponen-komponennya secara signifikan mempertinggi tingkat asosiasi, tetapi tidak ditemukan bukti perbedaan asosiasi antar komponen dari arus kas investasi.

4. Wilson (1987)

Menemukan bukti adanya asosiasi antara return saham dengan informasi baru mengenai kas dari operasi yang ditimbulkan selama jangka waktu tersebut, tetapi tidak memperoleh bukti cukup untuk membuat kesimpulan bahwa noncurrent accruals dan modal kerja dari komponen operasi laba memiliki kandungan informasi incremental melebihi laba.

5. Wilson dalam Black (1998)

Komponen akrual total dan kas dari laba mempunyai kandungan informasi inkremental melebihi laba itu sendiri dan bahwa komponen akrual total dari laba mempunyai kandungan informasi inkremental melebihi komponen kas. 
Noncurrent accruals tidak memiliki kandungan informasi incremental melebihi modal kerja dari operasi.

6. Rayburn dalam Atmini (2002)

Menemukan asosiasi antara arus kas dan akrual agregat dengan abnormal returns tetapi hasil untuk komponen akrual kurang konsisten.

b. Penelitian di Indonesia

1. Baridwan (1997)

Menemukan bukti bahwa pengungkapan informasi arus kas memberikan informasi tambahan bagi para pemakai laporan keuangan.

2. Beza dan Naim (1998)

Menemukan bukti bahwa pada saat perusahaan mengumumkan laba tahunan, volume perdagangan saham meningkat secara signifikan dibandingkan dibandingkan dengan saat sebelum pengumuman. Volume perdagangan yang tidak diharapkan berkorelasi positif dengan nilai absolute besarnya laba yang tidak diharapkan tetapi berkorelasi negatif dengan ukuran perusahaan.

3. Hastuti dan Sudibyo dalam Atmini (2002)

Memberikan bukti empiris bahwa para investor sudah memanfaatkan informasi yang terkandung dalam laporan keuangan Desember 1993 dan 1994 untuk pengambilan keputusan investasi. Rata-rata volume perdagangan saham relatif setelah publikasi laporan arus kas menunjukkan perbedaan yang signifikan dibandingkan dengan sebelum adanya laporan arus kas.

4. Suadi (1998)

Menemukan bukti bahwa laporan arus kas berhubungan dengan jumlah pembayaran dividen yang terjadi dalam satu tahun setelah terbitnya laporan arus kas. Laporan arus kas mempunyai kandungan informasi dan bermanfaat bagi para pemegang saham.

5. Triyono dalam Atmini (2002)

Menemukan bukti bahwa total arus kas tidak mempunyai hubungan yang signifikan dengan harga saham, tetapi dari hasil analisis ditemukan bahwa pemisahan total arus kas ke dalam tiga komponen arus kas, yaitu arus kas operasi, pendanaan, dan investasi, mempunyai hubungan yang signifikan denga harga saham.

6. Utami dan Suharmadi dalam Atmini (2002) 
Memperoleh bukti empiris bahwa informasi penghasilan perusahaan berpengaruh terhadap harga saham di BEJ.

\section{B. KONSEP SIKLUS HIDUP PERUSAHAAN}

Teori product life cycle beranggapan bahwa produk (produk=industri) akan mengalami evolusi. Evolusi tersebut melalui beberapa fase, yaitu fase perkenalan (introduction phase), fase pertumbuhan (growth phase), fase kematangan (maturity phase), dan fase penurunan (decline phase). Titik-titik fase atau tahap siklus hidup tersebut ditentukan dari dua hal yaitu volume penjualan dan laba rugi perusahaan dari tiap fase evolusi akan berpengaruh terhadap strategi, kompetisi, dan kinerja perusahaan (Porter; Grant dalam Habbe dan Hartono, 2001).

Siklus hidup produk adalah suatu konsep penting yang memberikan pemahaman tentang dinamika kompetitif suatu produk. Seperti halnya dengan manusia, suatu produk juga memiliki siklus atau daur hidup. Siklus Hidup Produk (Product Life Cycle) ini yaitu suatu grafik yang menggambarkan riwayat produk sejak diperkenalkan ke pasar sampai dengan ditarik dari pasar . Siklus Hidup Produk ini merupakan konsep yang penting dalam pemasaran karena memberikan pemahaman yang mendalam mengenai dinamika bersaing suatu produk. Konsep ini dipopulerkan oleh Levitt (1978) yang kemudian penggunaannya dikembangkan dan diperluas oleh para ahli lainnya.

Ada berbagai pendapatan mengenai tahap - tahap yang ada dalam Siklus Hidup Produk suatu produk. Ada yang menggolongkannya menjadi introduction, growth, maturity, decline dan termination. Sementara itu ada pula yang menyatakan bahwa keseluruhan tahap - tahap Siklus Hidup Produk terdiri dari introduction (pioneering), rapid growth (market acceptance), slow growth (turbulance), maturity (saturation), dan decline (obsolescence). Meskipun demikian pada umumnya yang digunakan adalah penggolongan ke dalam empat tahap, yaitu introduction, growth, maturity dan decline.

Menurut Basu Swastha (1984:127-132), daur hidup produk itu di bagi menjadi empat tahap, yaitu :

1. Tahap perkenalan (introduction).

Pada tahap ini, barang mulai dipasarkan dalam jumlah yang besar walaupun volume penjualannya belum tinggi. Barang yang di jual umumnya barang baru (betul-betul baru) Karena masih berada pada tahap permulaan, biasanya 
ongkos yang dikeluarkan tinggi terutama biaya periklanan. Promosi yang dilakukan memang harus agfesif dan menitikberatkan pada merek penjual. Di samping itu distribusi barang tersebut masih terbatas dan laba yang diperoleh masih rendah.

2. Tahap pertumbuhan (growth).

Dalam tahap pertumbuhan ini, penjualan dan laba akan meningkat dengan cepat. Karena permintaan sudah sangat meningkat dan masyarakat sudah mengenal barang bersangkutan, maka usaha promosi yang dilakukan oleh perusahaan tidak seagresif tahap sebelumnya. Di sini pesaing sudah mulai memasuki pasar sehingga persaingan menjadi lebih ketat. Cara lain yang dapat dilakukan untuk memperluas dan meningkatkan distribusinya adalah dengan menurunkan harga jualnya.

3. Tahap kedewasaan (maturity).

Pada tahap kedewasaan ini kita dapat melihat bahwa penjualan masih meningkat dan pada tahap berikutnya tetap. Dalam tahap ini, laba produsen maupun laba pengecer mulai turun. Persaingan harga menjadi sangat tajam sehingga perusahaan perlu memperkenalkan produknya dengan model yang baru. Pada tahap kedewasaan ini, usaha periklanan biasanya mulai ditingkatkan lagi untuk menghadapi persaingan.

4. Tahap kemunduran (decline)

Hampir semua jenis barang yang dihasilkan oleh perusahaan selalu mengalami kekunoan atau keusangan dan harus di ganti dengan barang yang baru. Dalam tahap ini, barang baru harus sudah dipasarkan untuk menggantikan barang lama yang sudah kuno. Meskipun jumlah pesaing sudah berkurang tetapi pengawasan biaya menjadi sangat penting karena permintaan sudah jauh menurun.Apabila barang yang lama tidak segera ditinggalkan tanpa mengganti dengan barang baru, maka perusahaan hanya dapat beroperasi pada pasar tertentu yang sangat terbatas' Altematif-alternatif yang dapat dilakukan oleh manajemen pada saat penjualan menurun antara lain:

a. Memperbarui barang (dalam arti fungsinya).

b. Meninjau kembali dan memperbaiki progrcm pemasaran serta program produksinya agar lebih efisien.

c. Menghilangkan ukuran, warna, dan model yang kurang baik. 
d. Menghilangkan sebagian jenis barang untuk mencapai laba optimum pada barang yang sudah ada.

e. Meninggalkan sama sekali barang tersebut.

Strategi Siklus Hidup Produk (Product Life Cycle)

Bila Siklus Hidup Produk dianggap sebagai nilai strategik bagi suatu perusahaan, maka manajernya harus dapat menentukan dimana posisi Siklus Hidup Produk produknya. Identifikasi tahapan Siklus Hidup Produk ini dapat ditentukan dengan kombinasi tiga faktor yang menunjukan ciri status produk dan membandingkan hasilnya dengan pola yang umum. Tahap Siklus Hidup Produk suatu produk dapat ditentukan dengan mengidentifikasikan statusnya dalam market volume, rate of change of market volume. Dalam keempat tahap dari analisa Siklus Hidup Produk ini memiliki beberapa strategi (Kotler, 1997) yaitu :

1. Tahap Perkenalan (Introduction)

a. Strategi peluncuran cepat (rapid skimming strategy)

Peluncuran produk baru pada harga tinggi dengan tingkat promosi yang tinggi. Perusahaan berusaha menetapkan harga tinggi untuk memperoleh keuntungan yang mana akan digunakan untuk menutup biaya pengeluaran dari pemasaran.

b. Strategi peluncuran lambat (slow skimming strategy)

Merupakan peluncuran produk baru dengan harga tinggi dan sedikit promosi. Harga tinggi untuk memperoleh keuntungan sedangkan sedikit promosi untuk menekan biaya pemasaran.

c. Strategi penetrasi cepat (rapid penetration strategy)

Merupakan peluncuran produk pada harga yang rendah dengan biaya promosi yang besar. Strategi ini menjanjikan penetrasi pasar yang paling cepat dan pangsa pasar yang paling besar.

d. Strategi penetrasi lambat (slow penetration strategy)

Merupakan peluncuran produk baru dengan tingkat promosi rendah dan harga rendah. Harga rendah ini dapat mendorong penerimaan produk yang cepat dan biaya promosi yang rendah.

2. Tahap Pertumbuhan (Growth)

Selama tahap pertumbuhan perusahaan menggunakan beberapa strategi untuk mempertahankan pertumbuhan pasar yang pesat selama mungkin dengan cara: 
a. Meningkatkan kualitas produk serta menambahkan keistimewaan produk baru dan gaya yang lebih baik.

b. Perusahaan menambahkan model - model baru dan produk - produk penyerta (yaitu, produk dengan berbagai ukuran, rasa, dan sebagainya yang melindungi produk utama)

c. Perusahaan memasuki segmen pasar baru.

d. Perusahaan meningkatkan cakupan distribusinya dan memasuki saluran distribusi yang baru.

e. Perusahaan beralih dari iklan yang membuat orang menyadari produk (product awareness advertising) ke iklan yang membuat orang memilih produk (product preference advertising)

f. Perusahaan menurunkan harga untuk menarik pembeli yang sensitif terhadap harga dilapisan berikutnya.

\section{Tahap Kedewasaan (Maturity)}

a. Perusahaan meninggalkan produk mereka yang kurang kuat dan lebih berkonsentrasi sumber daya pada produk yang lebih menguntungkan dan pada produk baru.

b. Memodifikasi pasar dimana perusahaan berusaha untuk memperluas pasar untuk merek yang mapan.

c. Perusahaan mencoba menarik konsumen yang merupakan pemakai produknya.

d. Menggunakan strategi peningkatan keistimewaan (feature improvement) yaitu bertujuan menambah keistimewaan baru yang memperluas keanekagunaan, keamanan atau kenyaman produk.

e. Strategi defensif dimana perusahaan untuk mempertahankan pasar yang mana hasil dari strategi ini akan memodifikasi bauran pemasaran.

f. Strategi peningkatkan mutu yang bertujuan meningkatkan kemampuan produk, misalnya daya tahan, kecepetan, dan kinerja produk.

g. Strategi perbaikan model yang bertujuan untuk menambah daya tarik estetika produk seperti model, warna, kemasan dan lain - lain.

h. Menggunakan take-off strategy yang mana marupakan salah satu strategi yang digunakan untuk mencapai fase penerimaan konsumen baru, strategi ini dapat memperbaharui pertumbuhan pada saat produk masuk dalam kematangan. 
4. Tahap Penurunan (Decline)

a. Manambah investasi agar dapat mendominasi atau menempati posisi persaingan yang baik.

b. Mengubah produk atau mencari penggunaan/manfaat baru pada produk

c. Mencari pasar baru

d. Tetap pada tingkat investasi perusahaan saat ini sampai ketidakpastian dalam industri dapat diatasi

e. Mengurangi investasi perusahaan secara selesktif dengan cara meninggalkan konsumen yang kurang menguntungkan.

f. Harvesting strategy untuk mewujudkan pengembalian uang tunai secara cepat

g. Meninggalkan bisnis tersebut dan menjual aset perusahaan.

Teori siklus hidup perusahaan adalah perluasan dari konsep siklus hidup produk yang dibangun dalam pemasaran dan ekonomi mikro (Mueller; Rink dan Swan seperti dikutip Black, 1998). Produk individu (barang atau jasa) bergerak melalui kurang lebih empat fase yang diidentifikasikan: start-up, growth, maturity, dan decline. Hampir sama, perusahaan dapat dijelaskan ke dalam tahap siklus hidup yang tergantung pada portfolio produk.

Siklus hidup perusahaan terdiri atas empat tahap utama, yaitu pioneering, expansion, maturity, dan decline (Pashley dan Philippatos, dalam Atmini, 2002). Black (1998) menyebut tahap pioneering sebagai tahap start-up dan menyebut tahap expansion sebagai tahap growth.

\section{HUBUNGAN SIKLUS HIDUP PERUSAHAAN DENGAN INFORMASI LABA DAN ARUS KAS}

Ekspektasi karakteristik tahap siklus hidup diperoleh dari Stickney (1996) dan White dkk (1997) seperti dikutip Black (1998). Masing-masing tahap siklus hidup perusahaan berhubungan dengan besarnya laba dan arus kas yang dihasilkan perusahaan. Nilai perusahaan menurut Myers dalam Black (1998) dapat menjelaskan hubungan ini.

Nilai perusahaan terdiri dari dua komponen, assets in place dan growth opportunities. Pada tahap start-up, perusahaan memiliki sedikit aktiva, sehingga jika ada, terdapat sedikit arus kas operasi positif atau laba positif. Informasi operasi kemungkinan tidak memiliki value-relevance dengan harga saham. 
Sebagian besar porsi nilai perusahaan terdiri atas growth opportunities. Perusahaan membutuhkan pendanaan untuk melakukan investasi dalam growth opportunities dengan net present value positif.

Myers dalam Black (1998) menyatakan bahwa hubungan antara masing - masing tahap siklus hidup perusahaan dengan besarnya laba dan arus kas yang dihasilkan perusahaan dapat dijelaskan melalui konsep nilai perusahaan, dimana terdiri dari assets in place dan growth opportunities (kesempatan tumbuh), dengan proporsi yang berbeda tergantung tahap siklus hidup perusahaan.

\section{Tahap start - up (Perkenalan)}

Pada tahap start - up, perusahaan berusaha mendapatkan pangsa pasar dan belum memperoleh banyak pendapatan. Perusahaan banyak melakukan pengeluaran kas untuk pengembangan produk, pengembanga pasar, dan ekspansi kapasitas. Kondisi ini menekan laba jangka panjang di masa depan sehingga diharapkan melaporkan laba negatif (Anthony, et.al, 1992). Hal ini didukung oleh Hayn (1995) yang menemukan bukti bahwa perusahaan kecil, yang kemungkinan merupakan perusahaan yang berada pada tahap start - up atau growth mempunyai kemungkinan lebih besar untuk melaporkan kerugian daripada perusahaan yang lebih besar. Walaupun laba negatif, perusahaan memiliki kesempatan tumbuh yang besar dan prospek untuk menghasilkan laba positif di masa depan sehingga diharapkan nilai pasar ekuitasnya tinggi dan laba diharapkan berhubungan negatif dengan nilai pasar ekuitas. Sama halnya dengan laba yang dilaporkan negatif, AKO dan AKI juga bernilai negatif terhadap nilai pasar ekuitas. Sedangkan kebutuhan dana yang besar dimana difokuskan untuk keperluan pendanaan menyebabkan AKP bernilai positif.

Menurut Pashley dan Philippatos seperti dikutip Atmini (2002), ciri-ciri perusahaan start-up adalah volume penjualan awalnya rendah, menderita kerugian akibat adanya start-up costs, dan tingkat likuiditasnya rendah. Sebagian besar dana adalah dana pinjaman. Umumnya perusahaan tidak membagikan dividen.

Pada tahap start - up, perusahaan memiliki sedikit aktiva, sehingga jika ada terdapat sedikit arus kas operasi positif atau laba positif. Informasi operasi kemungkinan tidak memiliki value - relevance dengan harga saham. Sebagian besar porsi nilai perusahaan terdiri atas kesempatan tumbuh. Perusahaan 
membutuhkan pendanaan untuk melakukan investasi dalam kesempatan tumbuh dengan net present value positif.

\section{Tahap Growth (Pertumbuhan)}

Pada tahap growth, perusahaan sudah memperoleh pangsa pasar, mengalami peningkatan penjualan, keuntungan, likuiditas, dan peningkatan rasio ekuitas terhadap utang, serta mulai membayar dividen. Perusahaan mulai melakukan diversifikasi dalam lini produk yang berhubungan erat (Pashley dan Philippatos seperti dikutip Atmini, 2002).

Dalam hal kinerja, Porter (1980) mengemukakan bahwa perusahaan yang berada ada fase pertumbuhan mempunyai margin dan profit serta pertumbuhan penjualan yang relatif lebih tinggi dibanding pada fase kematangan dan fase penurunan. Namun, return on investment (ROI) pada fase ini relatif lebih kecil dibanding perusahaan yang berada pada fase kematangan (Anderson dan Zeithmal, 1984). Hal ini dikarenakan pada fase perkenalan dan pertumbuhan, perusahaan masih dalam taraf membangun (build) yang masih terus melakukan investasi. Sedangkan pada fase kematangan dan penurunan, perusahaan sudah berada pada taraf panen (harvest). Pada fase pertumbuhan, sistem pengendalian manajemen yang diterapkan tidak ketat (Anthony dan Govindarajan, 2009).

Pada tahap growth, investasi dalam kesempatan tumbuh telah dimulai, dan perusahaan telah memperoleh sejumlah pendanaan, rasio nilai assets in place terhadap nilai perusahaan lebih tinggi daripada dalam tahap start - up. Assets in place lebih mewakili kesempatan tumbuh serta telah menghasilkan laba bersih dan arus kas operasi. Kesempatan tumbuh merupakan komponen utama nilai perusahaan dan perusahaan masih berusaha untuk memperoleh pendanaan.

AKO pada tahap ini bernilai positif. Hal ini mencerminkan realitas ekonomi perusahaan yang baik sehingga nilai pasar ekuitas diharapkan tinggi dan berhubungan positif dengan nilai pasar ekuitas. AKI bernilai negatif, hal ini mencerminkan bahwa perusahaan masih memiliki peluang melakukan investasi, memiliki kesempatan tumbuh dan prospek yang baik di masa depan sehingga diharapkan nilai pasar ekuitasnya tinggi. Sedangkan AKP pada tahap ini bernilai positif dengan nilai pasar ekuitas.

\section{Tahap Mature (Kedewasaan)}

Pada tahap maturity, perusahaan mengalami puncak tingkat penjualan tetapi mengalami penurunan laba akibat kompetisi harga. Tingkat likuiditasnya 
tinggi dan perusahaan menjadi 'cash flow'. Perusahaan membayar dividen yang tinggi. Akusisi eksternal merupakan cara yang menarik bagi perusahaan untuk menginvestasikan dana yang berlebih secara menguntungkan (Pashley dan Philippatos seperti dikutip Atmini, 2002). AKO pada tahap ini bernilai positif.

Pada tahap mature, nilai kesempatan tumbuhn dibandingkan nilai assets in place lebih rendah daripada dalam tahap start - up dan growth. Perusahaan berada pada tahap pertumbuhan yang moderat atau rendah dan sebagian besar kebutuhan arus kasnya dihasilkan secara internal. Assets in place mencerminkan kesempatan dalam bentuk ekspansi. AKO, AKI, dan AKP pada tahap ini sama dengan tahap growth.

\section{Tahap Decline (Penurunan)}

Permintaan akan produk yang diproduksi perusahaan yang berada pada tahap decline sangat rendah. Perusahaan, terutama yang berada pada akhir tahap decline, mengalami penurunan penjualan secara signifikan sehingga terjadi kerugian dan pembayaran dividen terhenti. Pada tahap decline ini, posisi kompetitif perusahaan sudah tidak menarik lagi, persaingan semakin tajam, dan pangsa pasar potensialnya semakin sempit (Anthony, et. al,1992).

Pada tahap decline, perusahaan memiliki kesempatan tumbuh yang terbatas, menghadapi persaingan yang semakin tajam, pangsa pasar potensial yang semakin sempit, dan ekspansi yang semakin tidak menguntungkan. Penurunan ini tidak selalu mengarahkan perusahaan menuju kegagalan. Perusahaan dapat regenerasi dengan investasi pada lini produk baru dan teknologi, dan kembali ke tahap growth atau mature, atau mencegah kegagalan untuk beberapa tahun. Arus kas likuidasi, meskipun demikian, mungkin tidak dapat sejauh tahap lain (atau dapat menghasilkan profitabilitas lebih tinggi). Realisasi investor pada perusahaan decline, growth opportunities lebih terbatas

Perusahaan mengalami penurunan penjualan yang menyebabkan kondisi ekonomi perusahaan memburuk. Pada tahap ini laba, AKO, dan AKP dilaporkan negatif. Namun, perusahaan masih memiliki kesempatan untuk kembali ke tahap growth dan mature atau mampu menunda kegagalan. Dengan kesempatan investasi yang terbatas, menyebabkan perusahaan lebih banyak menjual aktiva sehingga AKI bernilai positif. Dan kesemuanya berhubungan positif dengan nilai pasar ekuitas. 


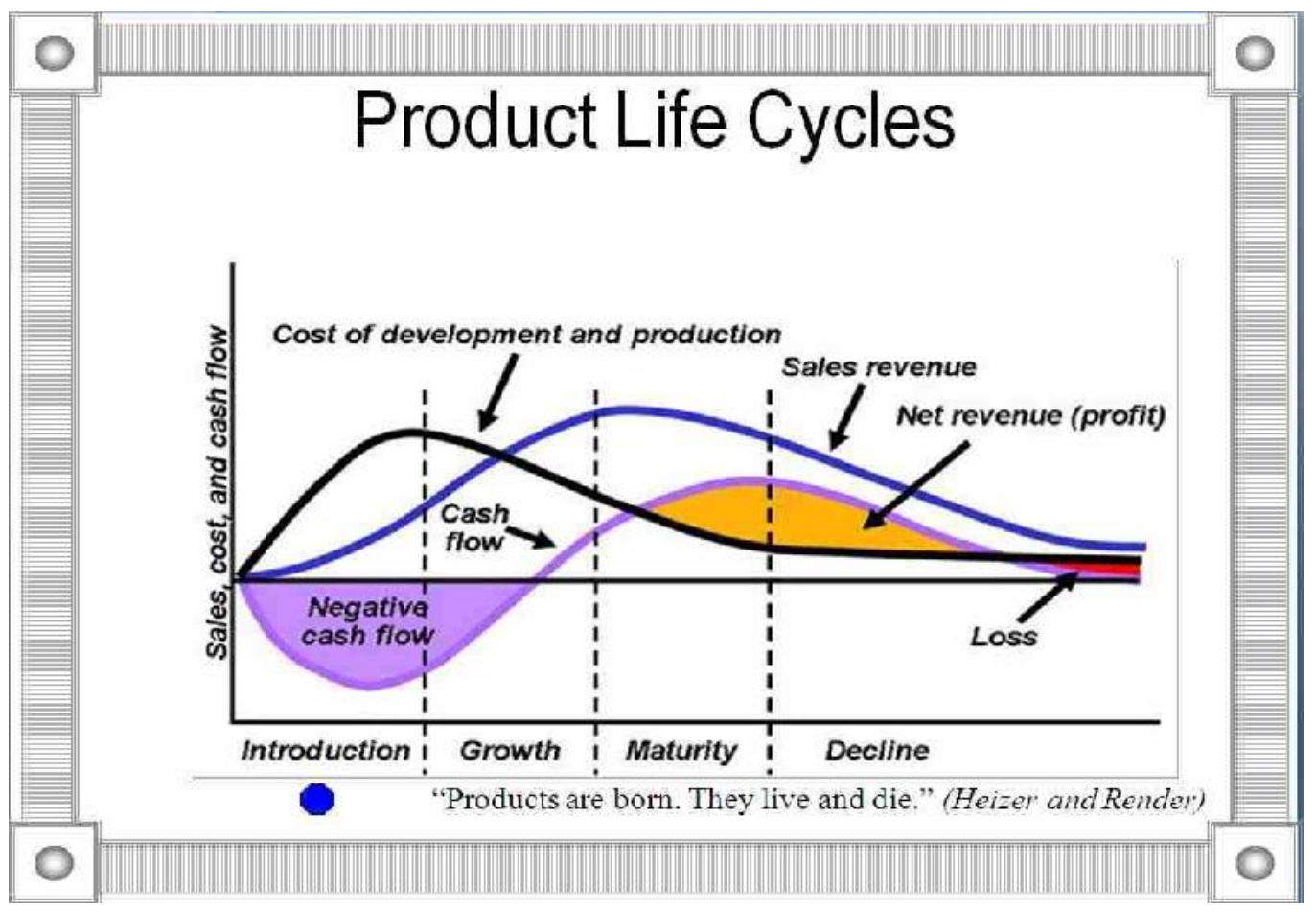

Berikut beberapa ringkasan hasil penelitian - penelitian mengenai informasi laba dan arus kas dan mempertimbangkan faktor siklus hidup perusahaan.

1. Anthony dan Ramesh dalam Black (1998)

Menunjukkan bahwa respon pasar terhadap dua ukuran kinerja akuntansi, yaitu pertumbuhan penjualan dan investasi modal, merupakan fungsi dari tahap siklus hidup perusahaan, bahkan setelah dilakukan pengendalian terhadap ukuran perusahaan serta kesalahan pengukuran dalam proksi ukuran kinerja.

2. Black (1998)

Memperoleh bukti bahwa siklus hidup perusahaan mempengaruhi valuerelevance ukuran laba dan arus kas. Laba berhubungan positif dengan nilai pasar ekuitas pada tahap mature. Arus kas operasi berhubungan positif dengan nilai pasar ekuitas pada tahap growth, mature, dan decline. Arus kas investasi berhubungan negatif dengan nilai pasar ekuitas pada tahap start-up dan growth serta arus kas pendanaan berhubungan positif dengan nilai pasar ekuitas pada tahap start-up, growth, dan decline serta berhubungan negatif dengan nilai pasar ekuitas pada tahap mature.

3. Dechow dalam Black (1998)

Menemukan bukti bahwa arti penting akrual meningkat dengan semakin pendeknya interval pengukuran kinerja, semakin besarnya volatilitas persyaratan 
modal kerja serta aktifitas investasi dan pendanaan, dan semakin panjangnya siklus operasi perusahaan. Arus kas lebih banyak mengalami masalah berkaitan dengan matching dan timing, sehingga kemampuan arus kas dalam mencerminkan kinerja perusahaan berkurang.

4. Habbe dan Hartono (2001)

Menemukan bukti bahwa pertumbuhan laba dan pertumbuhan penjualan perusahaan prospector lebih besar daripada perusahaan defender. Dividend pay out dan reaksi padar antara perusahaan prospector dan defender tidak berbeda secara signifikan. Besarnya pertumbuhan laba dan pertumbuhan penjualan perusahaan prospector secara signifikan mempengaruhi besarnya abnormal returns, sedangakan untuk perusahaan defender besarnya abnormal returns hanya dipengaruhi oleh besarnya pertumbuhan laba. Dividend pay out tidak mempengaruhi besarnya abnormal returns untuk perusahaan prospector dan defender. Pengaruh besarnya pertumbuhan laba dan pertumbuhan penjualan terhadap besarnya abnormal returns antara perusahaan prospector dan defender tidak berbeda secara signifikan.

5. Atmini (2002)

Menemukan bukti bahwa:

a. Laba berhubungan positif dengan nilai pasar ekuitas pada tahap growth dan mature.

b. Arus kas operasi tidak berhubungan dengan nilai pasar ekuitas pada tahap growth, tetapi berhubungan positif dengan nilai pasar ekuitas pada tahap mature.

c. Arus kas investasi berhubungan negatif dengan nilai pasar ekuitas pada tahap growth dan pada tahap mature.

d. Arus kas pendanaan berhubungan positif dengan nilai pasar ekuitas pada tahap growth, dan berhubungan negatif pada tahap mature.

\section{KESIMPULAN}

Laba dan arus kas merupakan dua ukuran kinerja akuntansi perusahaan. Dengan melihat keduanya diharapkan investor dan kreditur dapat mengevaluasi kinerja perusahaan pada suatu saat tertentu. Namun pada kenyataanya, hanya sedikit perusahaan yang menggunakan baik laba dan arus kas untuk menilai kinerja manajemen. Agar dapat menggambarkan secara baik kondisi ekonomi serta prospek 
perusahaan di masa depan, maka yang harus dipertimbangkan selanjutnya adalah faktor siklus hidup perusahaan.

Berdasarkan kajian teoritis yang diuraikan di atas menunjukkan bahwa dengan mempertimbangkan faktor siklus hidup perusahaan, informasi laba dan arus kas memiliki incremental value - relevance yang sangat berguna bagi para investor dan kreditor untuk menilai kinerja akuntansi perusahaan ketika mereka menggunakan keduanya secara bersama - sama.

\section{DAFTAR PUSTAKA}

Anthony, R. N dan Govindarajan, V. 2009. Management Control System (Terjemahan).Edisi 11. Buku 1. Salemba Empat. Jakarta.

Atmini, Sari. 2002. Asosiasi Siklus Hidup Perusahaan dengan Incremental Valuerelevance Informasi Laba dan Arus Kas. Jurnal Riset Akuntansi Indonesia 5.3: 257-276.

Baridwan, Z. 1997. Analisis Nilai Tambah Informasi Laporan Arus Kas. Jurnal Ekonomi dan Bisnis Indonesia 12.2: 1-14.

Beza, B. dan A. Na'im. 1998. the Information Content of Annual Earnings Announcements a Trading Volume Approach. Jurnal Riset Akuntansi Indonesia1: 163-173.

Black, E. L. 1998. Life Cycle Impact on the Incremental Value - Relevance of earnings and Cash Flow Measures. Journal of Financial Statement Analysis 4: $40-57$.

Bowen, R. M., D. Burgstahler, amd L. A. Daley. 1987. The Incremental Information Content of Accruals versus Cash Floes. The Accounting Review 62: 723-747.

Habbe, A. H., dan J. Hartono. 2001. Studi terhadap Pengukuran Kinerja Akuntansi Perusahaan Prospektor dan Defender, dan hubungannya dengan Harga Saham: Analisis dengan Pendekatan Life Cycle Theory. Jurnal Riset Akuntansi Indonesia 4.1: 111-132. 
Niswonger, Warren, Reeve, dan Fees. 1999. Prinsip-prinsip Akuntansi. Jilid Kedua. Erlangga. Jakarta.

Suadi, A. 1998. Penelitian tentang manfaat Laporan Arus Kas. Jurnal Ekonomi dan Bisnis Indonesia: 91-97.

Wilson, G. P. 1987. The Incremental Information Content of Accruals and Cash Flows After Controlling for Earnings. The Accounting Review 62: 293-322.

\begin{abstract}
ABSTRAKSI
Kajian teoritis ini bertujuan untuk mengetahui incremental value - relevance informasi laba dan arus kas. Hal ini berkaitan dengan para investor dan kreditur sebagai pemakai informasi akuntansi yang mengandalkan informasi laba dalam menilai kinerja perusahaan. Sedangkan, arus kas menyajikan informasi tambahan dalam penilaian tersebut. Selain dua ukuran kinerja tersebut, siklus hidup perusahaan juga dapat memberikan gambaran yang lebih baik.

Metode yang digunakan dalam kajian teoritis ini adalah studi pustaka. Data yang dikumpulkan merupakan hasil penelitian di luar negeri dan di Indonesia. Penelitian yang dimaksud meneliti tentang informasi laba dan arus kas serta hubungan siklus hidup perusahaan dengan informasi laba dan arus kas.

Berdasarkan kajian teoritis yang dilakukan menunjukkan bahwa dengan mempertimbangkan faktor siklus hidup perusahaan, informasi laba dan arus kas memiliki incremental value - relevance yang sangat berguna bagi para investor dan kreditor untuk menilai kinerja akuntansi perusahaan ketika mereka menggunakan keduanya secara bersama - sama.
\end{abstract}

Kata kunci: incremental value - relevance, informasi laba, informasi arus kas, siklus hidup perusahaan. 
